\title{
IMPLEMENTATION OF AUTHENTIC LEARNING MODEL IN SOCIAL LEARNING FOR DEPELOPMENT OF STUDENT'S SOCIAL SKILLS \\ (Classroom Action Research at class of VII A in SMP Negeri 7 Bandung)
}

\author{
By \\ Dian Purnamasari \\ diian@live.com \\ Departmen of Social Studies Education \\ School of Postgraduate Indonesia University of Education
}

\begin{abstract}
This study originated from the writer's concern towards an issue occurred in seventh graders of SMP N 7 Bandung related to social skills of student. The issue is finding from conducted observation in several meetings of February 2014. Indicator of the problems which is encountered is low interest in cooperating, responsibility and tolerance of learners in learning process, less understanding of the meaning of social studies, low participation of learners in learning, unwell paradigm of social studies, lack of initiative participation in learning process, and low learning results. Reviewing the examined issues relate to the learning process, the researcher chose Classroom Action Research (CAR) with 4 cycles of David Hopkins research design. Alternative selected solutions, namely Authentic Learning Models. Implementation of authentic learning activities in social learning as an alternative in purpose to develope the social skills of students can be categorized in good level. The development of authentic learning in social learning can be seen from the development of social skills indicators such as able to cooperating with their groups, had a good responsibility, and able to apply owned knowledge, have perspective, empathized, and have selfknowledge to toleranced with others. Based on the findings in field could conclude from this study, including the first, well-designed research planning. Second, grow social skills of students in the
\end{abstract}

implementation of the learning activities using utilization of authentic learning carried out more focused and neatly on each cycle. Third, reflecting the constraints that are found in every cycle and overcome the constraints on the next cycle. Fourth, the solution in the constraints found in the utilization of authentic learing students experience positive changes that increase students' social skills. This reflects the achievement of all indicators of students'social skills. Fifth, after using utilization of Authentic Learning able to grow social skills in students.

Keywords: Authentic Learning, Social Skills

\section{PRELIMINARY}

Based on observations on Social Studies learning activities in class VII A SMP Negeri 7 Bandung found several problems including, first, by the time students are assigned to create a map individually, most of the peacock does not carry the equipment has been commissioned at the next meeting. It shows that students do not have the responsibility for the work to be done. Second, during the presentation of activities of students are cutting 
exposure and laughing at his friend who was reading the results of group discussions in class because there is a false statement, and not in accordance with the material. Third, at the time a student discussion activity seen only one man who is busy working on the task group and the other is even seen joking and walk around to see the results of work of other groups, so that when asked the question of the schools of the material only the students who do the work alone. Fourth, there are students who prefer working on tasks other subjects that they consider important than listening to a friend who was describing the results of group discussions in front of the class. Fifth, lack of initiative and responsibility of the student in the learning process so that the interaction is more done than teachers against pupils or one-way, the indicator is when the teacher gives students the opportunity to ask, there are only one or two students who responded to the question if the question posed a serious nature. Another indicator when teachers assign to bring tools for Social Studies practice only a few students who have prepared what to carry and use as well as when given homework most of the students do not come up and delay despite being given some time to process. These things add class less than optimal conditions, in order to identify the cause of the skill level of social class VII B SMP Negeri 7 Bandung relatively low.

In accordance with the purpose of education to prepare students to a better direction. One of the lessons is also important in the world of education in secondary level the Social Sciences. In the book Social Science Education, Hamid Hasan (1995, p. 14) stated that the Social Studies in general it can be said that there are two positions. First, the Social Studies as educational uses material from the disciplines of the social sciences as a source material. The second is the Social Studies Education is an education of the social sciences. In this case the Social Studies Education to focus more attention will thus perceived benefits in the everyday lives of students.

The results of the interview the researcher with the Social Studies teachers in class VII A SMP Negeri 7 Bandung gave the information that the problems which are prevalent in the students as described above, as a result of unapplicated learning concept of Social Studies well so the effect on the level of social skills of students is low. Ahmad in Koestyorini (2007, p. 12) mentions social skills a child's ability to react effectively and beneficial for the social environment is a prerequisite for better social adjustment, satisfying life, and socially acceptable. According to the observations of researchers, there are problems in class VII-A SMP Negeri 7 Bandung is the low social skills that include the values of tolerance, cooperation and responsibility. This is similar to the Jarolimek's statement (1977, p.4-5) "coverage social skills: Living and working together, taking turns, and being socialy sensitive. Learning self-control and selfdirection. Sharing ideas and experiences with others ..." Containing the understanding that social skills include teamwork, running errands and its parts, can control themselves and be able to exchange ideas with others. Then Lickona (2012, pp. 74-75) states that the moral values that should be developed in the school of responsibility, tolerance and cooperation.

Departing from the problems investigators offered an alternative solution as an effort to improve the social skills of students in Social Studies learning by applying an approach Contextual Learning, Teaching and Learning with authentic learning model. Authentic learning model by using learning 
resources from the environment so that students do not just memorize the material presented but also to understand the meaning contained in the concept of learning. Learning is designed as a process in which students search for answers about what to do with him, and tried to give meaning on his experience (Shapiro, 2006, in Sunaryo, 2013). Social Studies learning using authentic learning model in the proper sense because it is in line with the opinion of the Lombardi (2007, p.6) that authentic learning focuses on real-world, complex problems and solutions are applied, using a variety of role-playing activities, activities problem-based, case studies, and participate significantly in practice in the community as well as environmental learning is inherently multidisciplinary.

In the authentic learning process, students make observations in the field and see for yourself about the different things that happen in the environment and society. Visit and observation activities outside the classroom situation it aims to find connections between concepts or theories discussed in class with the real situation that occurred in the neighborhood. By discussing what they found in outside, to design the next action, then it shall be the collaboration of a group dynamics that will generate new ideas in addition to generating new ideas is also expected to generate an improvement in the Cognitive, Affective and Psychomotor on students especially to improve social skills as social capital itself in the life of society and the state subsequently. Thus researchers doing business in the form of research. The type of research that is selected is a Class Action Research for objects adapted to the characteristics and problems that arise in the classroom, and sulks from the preliminary observations made with the teachers Social Studies focusing research efforts on improved its teachers' social skills. Based on the background that has been stated above, researchers interested in conducting research in the class action A class VII SMP Negeri 7 Bandung entitled "IMPLEMENTATION OF AUTHENTIC LEARNING MODEL IN SOCIAL LEARNING FOR DEPELOPMENT OF STUDENT'S SOCIAL SKILLS".

In detail the problems found in this study can be formulated into the following questions:

1. How does the teacher plan learning authentic to develop social skills in social studies learning of students?

2. How does the learning process social studies through authentic learning model to improve the social skills of students in junior high school?

3. How does the performance of teachers in social studies learning through authentic learning model to improve the social skills of students?

4. What are the obstacles and difficulties teachers to improve students' social skills through authentic pembelajarn models in learning social studies in junior high school?

5. Efforts to whether the teachers in overcoming obstacles to improve the social skills of students through authentic learning model on learning social studies in junior high scool?

\section{METHOD}

Subjects in this study were students of class VII A in SMP Negeri 7 Bandung which amounted to 37 people. Class Action Research (Classroom Action Research) mentioned by Ebbut in Hopkins (2011, p. 
88 ), that the action research is the study of systemic efforts to improve the implementation of educational practices by a group of teachers to perform actions in learning, based on their reflections on the results of measures such action. Methods of classroom action research conducted to improve teaching and learning in class VII-A SMP Negeri 7 Bandung with materials about the environmental and social conditions are diverse ranging from the natural phenomena that occur in the global and happens in the environment around the student to progress people from era to era.

In this classroom action research, Hopkins researchers used the model cycle, because the researchers consider this cycle model in accordance with the theme and purpose of this research. Hopkins was adopted from David Hopkins (2011, pp. 90-98) This model shows the flow of activities of research that began with the four phases: planning (plan), action (act), observation (Observe), and reflection (Reflect).

Data processing techniques are observation, documentation studies, interviews and field notes. The data collection technique was conducted to collect data and then process them in order to achieve the research objectives. In this research, data analysis techniques were performed in two aspects, namely quantitative and qualitative. Through quantitative data processing, researchers can tell how much the critical thinking skills of the students at the beginning of learning and how big the changes that occur when a class action research was conducted, Komalasari (2010, p.156). Analyses were performed during the study conducted on the data as the preliminary study, further reduction, data presentation and conclusion and verification, Sanjaya (2011, p.106).
RESULTS The successful implementation of authentic learning models (authentic learning) in teaching social studies aimed at improving the social skills of students in class VII A SMP Negeri 7 Bandung. It is shown by the increase in the quality of the indicators of aspects of social skills that develop in a sustainable manner. In interviews with the social studies teacher, teachers respond positively to the materials given to students, it makes students become enthusiastic in learning Social Studies. Additionally the methods used in each study to hone the cognitive, affective, and psychomotor student.

From the observation of the student researchers in general each cycle has increased. In the first cycle is done as much as 3 action. Before taking action researchers do advance planning to prepare lesson plans, textbooks, pictures, videos, articles and learning resources such as the environment (Planted Forest Juanda, Dago Bandung) as a place for learning activities. In the first cycle of the materials used are materials discussed in the first cycle is "Indonesia Geographic Conditions". In action this first cycle of students who perform individual tasks and group work have very little social skills. In the process of observation or study outside the classroom later discussions to the presentation of this group of students still noisy, chatting with friends of different groups, dreamy, tasks other than learning social studies, and there are students who relied on his friend alone in the task group given by the teacher. In this first cycle of social skills of the students have not seen, the use of authentic learning secra not been fully accepted by the students. The first cycle is still dominated by the category of Less, which reached $77 \%$, Just $22 \%$, while the category of Good $0 \%$. 
In cycle II was done with 2 action. In the second cycle of the materials used "atmosphere and hydrosphere", with the theme of Climate Change. The first action carried out by conducting linking material and eco-transport activities outside the classroom. The next activity the teacher gives a task group to create a product that relates to the content being taught by a teacher and certainly associated with social skills meticulous researcher. Looking at the previous cycle in action this cycle started no progress compared to the previous cycle. In this second cycle of social skills using authentic learning have started to grow. This second cycle can be classified categories, which reached 33\% Less, Just $44 \%$, while $22 \%$ Good category.

In cycle III to do as much as 3 action. In action learning Social Studies Cycle III students to develop materials about the development of Indonesian society with authentic learning activities in Isola UPI Building and Role-Playing activities. At the time of the learning process in the third cycle is already menumbuhnya social skills of the second cycle. The level of tolerance, cooperation, and responsibility has increased compared to the previous cycle. But there are still some students who have not been on the growth of social skill. Seeing the state of teacher admonishing students to help each other and work together so that a given task can be completed on time, in this case the teacher should motivate students to always cultivate social skills in themselves. In this third cycle students who have already seen social skills. This proves that the social skills the students have started to grow. In the cycle into three categories Less than 11\%, 44\% Quite, and Good 44\%.
In the fourth cycle to do as much as 3 action. At the time of the learning process in the first act of this fourth cycle students analyze a video about the economic activities in the city of Bandung in groups. In the process of discussion with the group of students can give his opinion about issues he sees it. In the second act performed in Kosambi traditional market area. Students practice in an authentic learning to interact directly with the merchant. The process of learning outside the classroom activities conducted smoothly. Then the next action is the presentation of the task in the previous activity. The process of group presentations on the fourth cycle running smoothly. In the closing activity of teachers and students together to conclude the learning they learned and provide an evaluation of the material already learned. On this fourth cycle of social skills in the use of authentic learning in the students has been very visible. From the observation of the learning cycle IV social skills of students begin to look at the aspects of cooperation and responsibility to the group. This proves that their social skills in students. Indicators of achievement this cycle into four categories Less visible than the amount that has $0 \%$ Fair 33\%, and Good reach 66\%. Thus the researchers concluded to stop the cycle circuit in the fourth cycle is because the results indicators in both categories has reached more than $50 \%$ the number of students.

\section{CONCLUSION}

Based on the results of research and discussion, the general conclusion that can be drawn: the implementation model of authentic learning in social studies can foster social skills of students in 
class VII A SMP Negeri 7 Bandung. The conclusion of the researchers specifically formulated as follows:

1. Preparation of teachers in designing learning social studies through the application of models of authentic learning in class VII A. Preparation conducted by researchers in designing learning social studies teacher beforehand collaborate with partners to develop a lesson plan (RPP) based on the curriculum, syllabus, media and learning resources in the form of a social environment around the students that will be used. In preparation for learning social studies teachers use authentic learning to cultivate the students' social skills through learning IPS. Researchers also makes instruments used as research data collection tool that teachers and students observation sheet, interview sheets, documentation, and field notes.

2. Teachers in implementing the learning IPS with the implementation of authentic learning model to foster social skills. Implementation of social studies learning by applying the model of authentic learning using a variety of teaching methods including role-playing, program-based learning and project-based learning is by doing learning activities of individuals and groups in which each student activities are confronted with an issue surrounding the student to analyze the problems they encountered. Students demanded a solution to solve the problem through the ability of the students will show the social skills that students have as implement the cooperation, responsibility also tolerance to the surroundings.
3. Authentic learning model application in improving social skills in students performed on grade VII A, a researcher who served as teachers implementing the learning in class has a lot of obstacles in the learning process by applying a model of authentic learning. The constraints that researchers feel when the research is as follows:

a. Students are not used to learning outside the classroom,

b. When implementing authentic learning activities outside the classroom teacher is difficult to direct students distracted

c. There is still a lack of interaction between teachers and students in the cycle I and II.

d. Lack of motivation and tolerance with group members When deepening of the material the teacher is less explored more in the ability of students Based on the above statement can be concluded that the teacher should be able to facilitate the activities of students, creating a more conducive classroom during learning activities both inside and outside the classroom, and the teacher can act as mentors every learning activities undertaken by students.

4. Based on the constraints at the time of application possibilities were authentic learning model that has been stated above, the following attempt / solution to address the issue:

a. Teachers should familiarize students to learn to observe the social environment outside the classroom, 
b. Teacher seeks tougher on students and make learning more tersruktur enable students to easily directed.

c. Teachers should act more as a facilitator in the learning takes place outside and inside the classroom.

d. Teachers must be able to motivate students and instill character willing to sacrifice for the group.

e. Teachers should try to make the material presented is easy to understand students and provide an opportunity for students to be more active.

After using the application model of authentic learning in social studies learning can foster social skills class VII A. Judging from the indicators of achievement throughout students' social skills. Changes in the growth of social skills the students gained from the observation that poured through the records made by observers and researchers. As in the first cycle to the same job skills students still received less votes, on a cycle-II increased but is still within the scope of the category of enough votes. Cycle-III has been entered in both categories and the results of the study in cycle-IV was also an increase.

\section{REFERENCE}

Cliff Mims. (2008). Authentic Learning: A Practical Introduction \& Guide for Implementation. Journal Of Meridian. Diakses 12 Februari, dari http://www.ncsu.edu/meridian/win2003/authentic_ learning/index.pdf.
Hamid Hasan, Dkk .(2010). Inovasi Pembelajaran IPS : Implementasi Pembelajaran IPS dalam Menghadapi Tantangan Global. Bandung: Rizqi Press.

Hopkins, David.(2011). Panduan Guru Penelitian Tindakan Kelas. Yogyakarta: Pustaka Pelajar

Jarolimek, John.(1977). Social Studies Competencies And Skills. New York: Macmillan Publishing Co.,Inc

Koestyorini. (2007). Mengembangkan Keterampilan Sosial Bagi Remaja. Jurnal Likithapradnya. 10, 28-35.

Komalasari, Kokom. (2010). Pembelajaran Kontekstual : Konsep dan Aplikasi. Bandung: Refika Aditama

Kunandar. (2013). Penilaian Autentik: Penilaian Hasil Belajar Peserta Didik Berdasarkan Kurikuum 2013. Jakarta: Rajawali Pers

Lickona, Thomas. (2012). Mendidik Untuk Membentuk Karaketer. Jakarta: Bumi Aksara

Marilyn M. Lombardi. 2007. Authentic Learning for the 21st Century: An Overview. Jurnal Educause. Diakses 12 Februari 2014, dari http://www.educause.edu/ir/library/pdf/ELI5 014.pdf

Sanjaya, Wina. (2011). Penelitian Tindakan Kelas. Jakarta: Kencana

Sugiyono.(2011). Metode Penelitian Pendidikan : Pendekatan Kuantitatif, Kualitatif dan $R \& D$. Bandung: Alfabeta

UPIPRESS. (2013). Pidato Rektor UPI pada Wisuda Gelombang III Tahun 2013. http://berita.upi.edu/2013/12/18/pidatorektor-upi-pada-wisuda-gelombang-iiitahun-2013. Diakses 12 Februari 2014 